\title{
Antifungal Polyketides and Other Compounds from Amazonian Endophytic Talaromyces Fungi
}

\author{
Paulo H. F. da Silva, ${ }^{a}$ Mayane P. de Souza, ${ }^{b}$ Eliana A. Bianco, ${ }^{b}$ Sarah R. S. da Silva, ${ }^{b}$ \\ Liviane N. Soares, ${ }^{b}$ Emmanoel V. Costa, ${ }^{b}$ Felipe M. A. da Silva, ${ }^{b}$ Andersson Barison, ${ }^{c}$

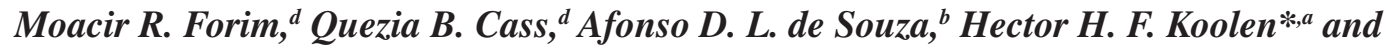 \\ Antonia Q. L. de Souza,
}

\author{
aPrograma de Pós-Graduação Mestrado em Biotecnologia e Recursos Naturais, \\ Escola Superior de Ciências da Saúde, Universidade do Estado do Amazonas, 69065-001 Manaus-AM, Brazil \\ ${ }^{b}$ Departamento de Química, Universidade Federal do Amazonas, 69067-005 Manaus-AM, Brazil \\ 'Departamento de Química, Universidade Federal do Paraná, 80210-170 Curitiba-PR, Brazil \\ ${ }^{d}$ Departamento de Química, Universidade Federal de São Carlos, 13565-905 São Carlos-SP, Brazil
}

${ }^{e}$ Faculdade de Ciências Agrárias, Universidade Federal do Amazonas, 69067-005 Manaus-AM, Brazil

\begin{abstract}
The continuous search for biologically active compound candidates pushes the pursuit of new substances produced by diverse organisms. Endophytic fungi are known as a promising source of metabolites with several biological activities. Based on the rich Amazonian biodiversity and the chemical potential of microbial sources, three Talaromyces strains, all major endophytes from their respective host plants, were studied aiming at the isolation of biologically active secondary metabolites. Through classical chromatographic approaches, 13 compounds were isolated from the antimicrobial extracts of the studied strains. From these, polyketides, steroids, anhydrides, and phenolic compounds were identified. Among them, two previously undescribed compounds were elucidated based on spectroscopic and spectrometric methods, a homodimer chromanone and a maleic anhydride methyl ester. The antimicrobial activity against a panel of pathogenic microorganisms from extracts, fractions, and isolated compounds was evaluated.
\end{abstract}

Keywords: Amazon region, cordyanhydrides, endophytic fungi, Talaromyces, xanthone dimers

\section{Introduction}

The Amazon rainforest possesses the richest biodiversity of all the earth's ecosystems, which includes an enormous diversity of microorganisms. ${ }^{1}$ From these, a vast range of fungi species play a vital role in the nutrient re-cycling, a vital process for the maintenance of the rainforest. ${ }^{2}$ This is one of the keys to sustain the Amazonian ecosystem. ${ }^{2}$ Among distinct types of fungi present in this environment, endophytes are receiving attention due to their ability to produce biologically active natural products. ${ }^{3,4}$

Endophytic strains of Talaromyces are still poorly studied, with few works reporting mainly secondary metabolites from the alkaloid, ${ }^{5}$ terpene, ${ }^{6}$ and polyketide

*e-mail: hkoolen@uea.edu.br classes. ${ }^{7}$ Some of the described compounds possess remarkable pharmacological activities. As examples, thermolides A-F from T. thermophilus with nematocidal activities comparable with commercial avermerctins ${ }^{8}$ and the steroid derivative wortmannin from T. wortmannin, ${ }^{9}$ which its semisynthetic derivatives are under phase II clinical trials for a new anticancer drug. ${ }^{10}$

Our research group has been interested in the chemistry of Amazonian endophytic fungi due to their abilities to produce metabolites with great interest in their ecological associations. ${ }^{11}$ In our continuing search for new substances, this study describes the chemical investigation of extracts produced by three endophytic strains belonging to the genus Talaromyces isolated from the roots of Duguetia stelechantha (strain $\mathrm{DgCr} 22.1 \mathrm{~b}$ ), root barks of Rollinia mucosa (strain AnspCr1 1.1), and the trabecular structure of Victoria amazonica (strain VrTrb2 1.1). 


\section{Experimental}

General

One-dimensional (1D) and two-dimensional (2D) nuclear magnetic resonance (NMR) spectroscopy data were acquired using an AVANCE 400 spectrometer (Bruker) operating at $9.4 \mathrm{~T}$ (400 and $100 \mathrm{MHz}$ for ${ }^{1} \mathrm{H}$ and ${ }^{13} \mathrm{C}$, respectively) and with an ASCEND 500 spectrometer (Bruker) at $11.7 \mathrm{~T}(500$ and $125 \mathrm{MHz}$ for ${ }^{1} \mathrm{H}$ and ${ }^{13} \mathrm{C}$, respectively). Deuterated chloroform $\left(\mathrm{CDCl}_{3}\right)$, dimethyl sulfoxide $\left(\mathrm{CD}_{3} \mathrm{SOCD}_{3}\right)$, and methanol $\left(\mathrm{CD}_{3} \mathrm{OD}\right)$ (Cambridge Isotope Labs) were used as NMR solvents. The semi-preparative high-performance liquid chromatography (HPLC) was carried out on a Shimadzu UFLC system (LC-6 AD pump, DGU-20A5 degasser, SPD-20AV UV detector, rheodyne injector, CBM-20A communication module). Analytical and preparative thin-layer chromatography (TLC) were run on $0.25 \mathrm{~mm}$ thick aluminum-backed silica-gel 60 plates type F-UV254/365 (Merck). The spots were visualized by exposure to ultraviolet light at 254 or $366 \mathrm{~nm}$, as well as by spraying with sulfuric vanillin reagent. High resolution electrospray ionization mass spectrometry (HRESIMS) measurements were recorded on a Waters Synapt HDMS instrument with a quadrupole timeof-flight (QTOF) geometry with an electrospray ionization (ESI) source. Optical rotations were obtained on a Jasco P-1020 polarimeter. All solvents used for chromatography and MS experiments were HPLC grade purchased from Tedia and water was purified by a Milli-Q system (Millipore).

Fungal material

The plants D. stelechantha and R. mисоsa (Annonaceae) were collected at the experimental farm of the Universidade Federal do Amazonas, Manaus City, Amazonas State, Brazil. The plant material of Victoria amazonica (Nymphaeaceae) was collected at the km 20 of the BR-194 highway, at the city of Careiro da Várzea, Amazonas State, Brazil. The procedures for fungi isolation and purification followed previously determined protocols. ${ }^{12}$ All isolated strains were identified according to traditional morphological criteria and by sequencing of the fungus internal transcribed spacer (ITS-1 to ITS-2) ribosomal deoxyribonucleic acid (rDNA). The obtained sequences were compared with previously deposited sequences from the GenBank. ${ }^{13}$ Vouchers were deposited at the fungal collection of the LabMicra group of the Universidade Federal do Amazonas. Strain $\mathrm{DgCr} 22.1 \mathrm{~b}$ was identified as Talaromyces stipitatus, while strains AnspCr1 1.1 and VrTrb2 1.1 were designated as Talaromyces sp., possibly undescribed species.

\section{Extract production}

All the studied strains were inoculated into 60 Erlenmeyer flasks containing $300 \mathrm{~mL}$ of potato dextrose broth medium (PDL) (strains AnspCr1 1.1, and VrTrb2 1.1) or international Streptomyces project 2 liquid medium (ISP2) (strain $\mathrm{DgCr} 2$ $2.1 b)$. The incubation period was 28 days for $T$. stipitatus $\operatorname{DgCr} 22.1$ b, 23 days for strain AnspCr1 1.1, and 30 days for strain VrTrb2 1.1, all growing at $28{ }^{\circ} \mathrm{C}$. After the complete growth, the mycelial mass was separated from the fermented broth by a vacuum filtration procedure. For all fungi, the liquid portion was extracted with ethyl acetate followed by an ethyl acetate/isopropanol 8:2 (v:v) mixture. Fungal cells were extracted with an ethyl acetate/methanol 1:1 (v:v) mixture followed by methanol. For the extraction procedures, solvents were evaporated under reduced pressure affording the crude extracts.

\section{Isolation of the chemical constituents}

All obtained extracts were assayed for their antimicrobial activities, being this the criteria for the extract selection for further fractionations. The ethyl acetate extract obtained from the broth of $T$. stipitatus $\mathrm{DgCr} 22.1 \mathrm{~b}$ (1.6 g) was fractionated over a silica gel column chromatography (CC) $(3 \times 30 \mathrm{~cm})$ eluted with hexane/ethyl acetate 7:3 (v:v), hexane/ethyl acetate 1:1 (v:v), ethyl acetate, and methanol (500 mL, each solvent) yielding six fractions (P-1 to P-6). The third fraction (P-3, $653 \mathrm{mg}$ ) eluted with ethyl acetate, displayed a slight increase in the observed activity. This fraction was subjected to another silica gel CC $(2 \times 15 \mathrm{~cm})$ eluted with an increasing gradient mixture of dichloromethane and ethyl acetate to give 16 sub-fractions (sP-1 to sP-16). The sub-fraction sP-6 (82.7 mg) eluted with dichloromethane/ethyl acetate 3:7 (v:v) was the only active fraction. From this sample, $80 \mathrm{mg}$ were separated by preparative TLC eluted with dichloromethane/methanol 95:5 (v:v) yielding 1 (retention factor (Rf) $0.83,4.9 \mathrm{mg}$ ), 2 (Rf 0.76, $2.1 \mathrm{mg}), 3(\operatorname{Rf} 0.69,3.0 \mathrm{mg}), 4(\operatorname{Rf} 0.58,1.8 \mathrm{mg})$, $5(\operatorname{Rf} 0.43,3.8 \mathrm{mg})$, and $6(\operatorname{Rf} 0.34,4.5 \mathrm{mg})$.

The ethyl acetate extract from the fermented broth of Talaromyces sp. VrTrb2 1.1 (4.13 g) was active against Ralstonia solanacearum, thus selected and submitted to liquid vacuum chromatography into a silica gel CC $(4 \times 30 \mathrm{~cm})$. The elution systems were: hexane/ethyl acetate $7: 3,1: 1$, and 3:7 (v:v), ethyl acetate and methanol resulting in seven fractions (F-1 to F-7, $500 \mathrm{~mL}$ for each solvent). The first two fractions (F-1 and F-2) were combined (1.41 g) (hexane/ethyl acetate $7: 3$ and $1: 1,(\mathrm{v}: \mathrm{v}))$, and chromatographed over a silica gel $\mathrm{CC}(1.5 \times 40 \mathrm{~cm})$ with hexane, ethyl acetate and methanol gradients affording eighteen sub-fractions (sF1-1 to sF1-18). 
After TLC analysis, sub-fractions 7, 8, and 9 were combined (187.3 mg). After TLC analysis, sF7-9 was subjected to reverse phase semi-preparative HPLC. An isocratic elution employing a $70 \%$ methanol at $8.7 \mathrm{~mL} \mathrm{~min}^{-1}$ flow rate and ultraviolet (UV) detection at $254 \mathrm{~nm}$ was performed to obtain 7 (7.2 $\mathrm{mg}$, retention time $\left.\left(t_{R}\right)=19.2 \mathrm{~min}\right)$. Direct fractionation of the methanol extract $(3.50 \mathrm{~g})$ from the mycelial mass of this fungus using a hexane, ethyl acetate, and methanol gradients over a silica gel CC $(4 \times 40 \mathrm{~cm})$ resulted in 26 fractions (T1-26). Fractions T-6, T-8, T-12, and T-15 displayed the presence of crystals. Washing with $n$-hexane and recrystallization with ethyl acetate afforded the isolated compounds $\mathbf{9}$ (10.2 mg), $\mathbf{1 0}$ (8.5 mg), $\mathbf{1 1}(12.3 \mathrm{mg})$, 12 (6.7 mg).

The fungus Talaromyces sp. AnspCr1 1.1 had its ethyl acetate extract from the fermented broth $(1.37 \mathrm{~g})$ initially fractionated over a silica gel CC $(3 \times 30 \mathrm{~cm})$. The elution was carried out with hexane/ethyl acetate 9:1 (v:v), hexane/ethyl acetate 1:1 (v:v), ethyl acetate, and methanol (500 mL for each solvent) yielding four fractions (A-1 to A-4). Fraction A-1 displayed the presence of crystals, which were manually separated and washed with hexane/dichloromethane 9:1 (v:v) yielding 13 (2.7 mg). Fraction A-2 (2.54 g, hexane/ethyl acetate 1:1, (v:v)) was subjected to another silica gel CC $(2 \times 15 \mathrm{~cm})$ employing a hexane and ethyl acetate gradient affording 24 sub-fractions (sA-1 to sA-24). The sub-fraction sA-18 (816 mg) was submitted to a semi-preparative HPLC (normal phase) with an isocratic elution of hexane/isopropanol 95:5 (v:v) at $8.0 \mathrm{~mL} \mathrm{~min}^{-1}$ and $\mathrm{UV}$ detection at $230 \mathrm{~nm}$, to re-isolate $6\left(22.6 \mathrm{mg}, \mathrm{t}_{\mathrm{R}}=8.46 \mathrm{~min}\right)$. The Fraction F21 was subjected to the same isolation process using $65 \%$ methanol as the mobile phase at $6.5 \mathrm{~mL} \mathrm{~min}^{-1}$ and UV detection at $310 \mathrm{~nm}$ to afford $8\left(9.4 \mathrm{mg}, \mathrm{t}_{\mathrm{R}}=2.97 \mathrm{~min}\right)$.

\section{Antimicrobial assay}

The preliminary antibacterial activity of the obtained extracts was determined according to the agar-diffusion method with its methodology being previously described elsewhere. ${ }^{11,15}$ The evaluation of the antimicrobial potential of pure compounds was assessed by the microbroth dilution method as recommended by the US National Committee for Clinical Laboratory Standards (NCCLS). ${ }^{11}$ The inhibition halo $(\mathrm{mm})$ for extracts and the minimal inhibitory concentrations (MICs, $\mu \mathrm{g} \mathrm{mL}^{-1}$ ) for pure compounds were evaluated against a panel of pathogenic microorganisms. Wild hospital strains of gram-positive Bacillus cereus, Staphylococcus aureus, gram-negative Escherichia coli, and a wild environmental strain of the plant pathogen $R$. solanacearum were used for the antibacterial assays.
The antifungal potential was evaluated against a wild soil strain of Penicillium avellaneum, and wild hospital strains of Candida albicans and Candida tropicalis. Tetracycline and ampicillin $\left(3 \mu \mathrm{g} \mathrm{mL}^{-1}\right)$, and ketoconazole $\left(4 \mu \mathrm{g} \mathrm{mL}^{-1}\right)$ (Table 3 ) were used as antibacterial and antifungal positive controls, respectively. Dimethyl sulfoxide (DMSO) 10\% was used as negative control.

\section{Artifact formation investigation}

To evaluate the possibility of forming methyl esters of cordyanhydrides as artifacts during fractionation procedures with silica gel, we performed a test experiment. The strain Talaromyces sp. VrTrb2 1.1, was re-cultivated and extracted using the same methodology (ethyl acetate) in a smaller scale. The obtained extract was dried, re-suspended in isopropanol/water (8:2, v:v), and analyzed by direct infusion atmospheric pressure chemical ionization mass spectrometry (DI-APCI-MS) in the positive mode using an LCQ-fleet ion trap mass spectrometer (Thermo). The MS parameters were as follows: positive polarity; corona voltage, $4 \mathrm{kV}$; sheath gas, 10 arbitrary units; auxiliary gas, 5 arbitrary units; sweep gas, 0 arbitrary units; capillary temperature, $200{ }^{\circ} \mathrm{C}$; capillary voltage, $40 \mathrm{~V}$; tube lens, $120 \mathrm{~V}$; microscans, 4; maximum injection time, $100000 \mathrm{~ms}$, and unitary resolution.

\section{Paecillin D (1)}

Yellow needle crystals; $[\alpha]_{\mathrm{D}}^{25}-65^{\circ}$ (c $0.45, \mathrm{CHCl}_{3}$ ); ${ }^{1} \mathrm{H}\left(500 \mathrm{MHz}, \mathrm{CDCl}_{3}\right)$ and ${ }^{13} \mathrm{C}\left(125 \mathrm{MHz}, \mathrm{CDCl}_{3}\right) \mathrm{NMR}$ data, see Table 1; HRESIMS calculated for $\mathrm{C}_{32} \mathrm{H}_{30} \mathrm{O}_{14}$ $[\mathrm{M}-\mathrm{H}]^{-}:$637.1563, found: 637.1553.

\section{Cordyanhydride A methyl ester (7)}

White amorphous solid; $[\alpha]_{\mathrm{D}}^{25}+3^{\circ}$ (c $0.90, \mathrm{CHCl}_{3}$ ); ${ }^{1} \mathrm{H}\left(400 \mathrm{MHz}, \mathrm{CDCl}_{3}\right)$ and ${ }^{13} \mathrm{C}\left(100 \mathrm{MHz}, \mathrm{CDCl}_{3}\right) \mathrm{NMR}$ data, see Table 2; HRESIMS calculated for $\mathrm{C}_{21} \mathrm{H}_{25} \mathrm{O}_{8}$ $[\mathrm{M}+\mathrm{H}]^{+}:$405.1544, found: 405.1530 .

\section{Results and Discussion}

\section{Isolated compounds}

All obtained extracts were tested for their antimicrobial activity. From the extracts that displayed preliminary antimicrobial activities (Table 3), several secondary metabolites were isolated. After careful analysis of spectroscopic and spectrometric data, 13 compounds were identified. From T. stipitatus $\operatorname{DgCr} 22.1 \mathrm{~b}$, the new compound $\mathbf{1}$ was identified, in addition to the polyketides: secalonic acid A (2), ${ }^{16}$ blennolide $\mathrm{G}(\mathbf{3}),{ }^{17}$ 
versixanthone A (4), ${ }^{18}$ penicillixanthone A (5), ${ }^{16}$ and paecillin B (6). ${ }^{19}$ Talaromyces sp. VrTrb2 1.1 yielded a novel substance (7) and the known compounds ergosterol (9), ${ }^{20}$ ergosterol peroxide (10), ${ }^{21}$ ergosta-4,6,8(14),22-tetraen- 3-one (11), ${ }^{22}$ and citric acid (12). ${ }^{12}$ From the fungus Talaromyces sp. AnspCr1 1.1 were isolated 6,8-dihydroxy3-methylisocoumarin (13) ${ }^{23}$ cordyanhydride B (8), ${ }^{24}$ and 6 (Figure 1).

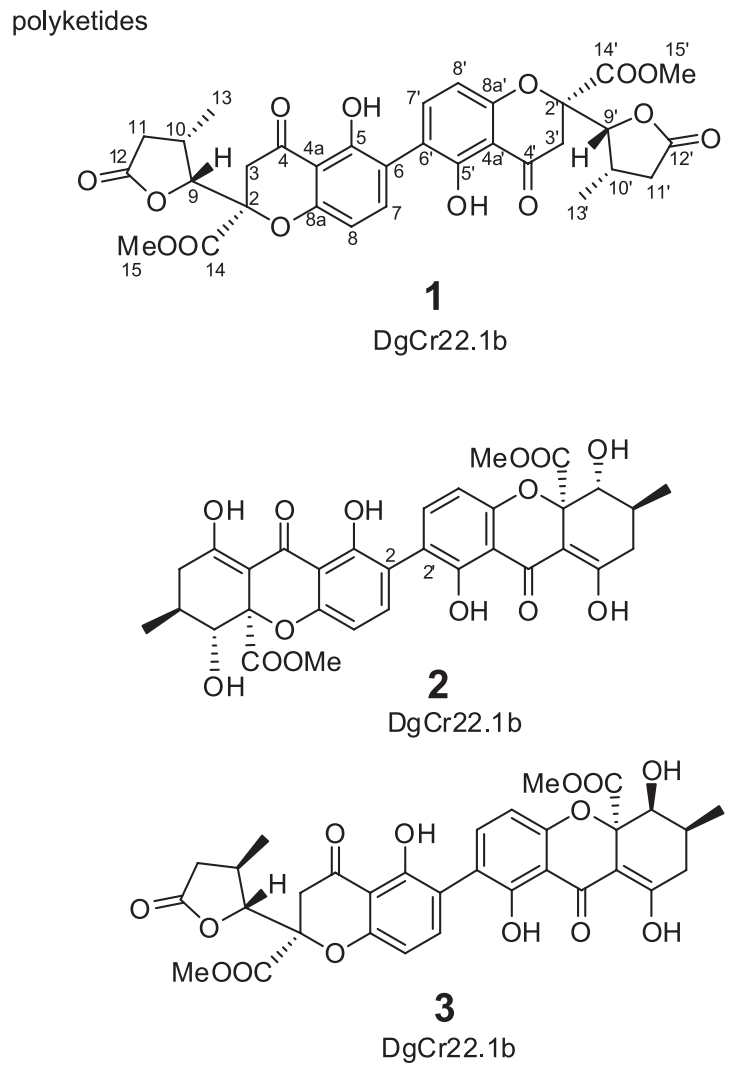

anhydrides<smiles>CCCCC1=C(CC(C)CC2=C(CCC(=O)OC)C(=O)OC2=O)C(=O)OC1=O</smiles>

7

VrTrb2.1.1.<smiles>[R]C1=C(CC(CC)CC2=C(CC3=C(CCCC(=O)O)C(=O)OC3=O)C(=O)OC2=O)C(CC2=C(/C=C/CC)C(=O)OC2=O)=C(CCCC(=O)O)C1=O</smiles>

AnspCr1.1.1.

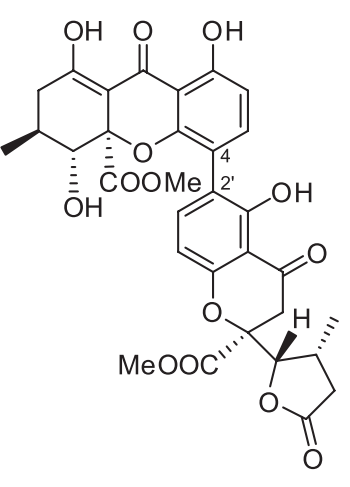

4

$\mathrm{DgCr} 22.1 \mathrm{~b}$

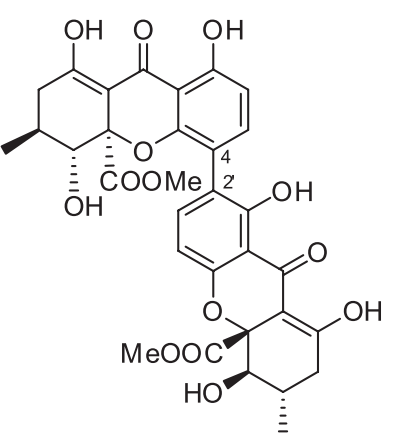

5
$\mathrm{DgCr} 22.1 \mathrm{~b}$<smiles>COC(=O)C1(C2OC(=O)CC2C)CC(=O)c2c(O)cccc2O1</smiles>

AnspCr1.1.1.

$\mathrm{Dg} \mathrm{Cr} 22.1 \mathrm{~b}$

steroids

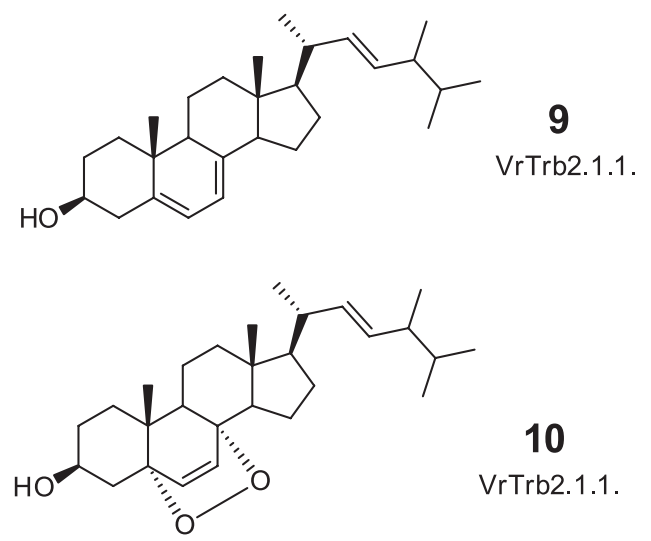

miscellaneous<smiles>O=C(O)CC(O)(CC(=O)O)CC(=O)O</smiles>

12<smiles>Cc1cc2cc(O)cc(O)c2c(=O)o1</smiles>

13 AnspCr1.1.1<smiles>CC(C)C(C)/C=C/[C@@H](C)[C@H]1CCC2=C3C=CC4=CC(=O)CC[C@]4(C)[C@H]3CC[C@]21C</smiles>

Figure 1. Chemical structures of the isolated compounds 1-13. 
Compound 1 was obtained as needle-like yellow crystals from the strains $\mathrm{DgCr} 22.1 \mathrm{~b}$ and $\operatorname{VrTrb} 21.1$ as a major compound in its correspondent fraction. Its molecular formula of $\mathrm{C}_{32} \mathrm{H}_{30} \mathrm{O}_{14}$ was determined from its HRESIMS $\left(\mathrm{m} / \mathrm{z} 637.1553[\mathrm{M}-\mathrm{H}]\right.$, calculated 637.1563) and ${ }^{13} \mathrm{C} \mathrm{NMR}$ data. The ${ }^{1} \mathrm{H}$ NMR spectrum displayed an unshielded signal at $\delta 11.92$ (s, OH-5), in addition to aromatic and carbinolic signals. The ${ }^{13} \mathrm{C}$ NMR spectrum indicated 16 carbons in $\mathbf{1}$, thus, this compound was assigned as a homodimer structure. A comparative analysis of the NMR data with the literature indicated that this compound was a xanthone derivative. ${ }^{25}$ The heteronuclear multiple bond correlations (HMBC) of the hydrogens; OH-5 with $\delta 107.5$ (C-4a), 117.6 (C-6), and 159.2 (C-5), $\delta 7.54$ (d, $J 8.5 \mathrm{~Hz}, \mathrm{H}-7)$ with $\delta 158.4$ (C-8a), and C-6, and from $\delta 6.64(\mathrm{~d}, J 8.5 \mathrm{~Hz}, \mathrm{H}-8)$ with $\mathrm{C}-4 \mathrm{a}$, C-6, and C-8a confirmed that 1 was a xanthone homodimer bearing a 6-6' linkage for the two monomers (Figures 2a and 2b). A deep analysis of the NMR signals indicated that the monomers were 2,2-disubstituted chromanones with identical stereochemistries. The connectivity between the chromanone monomeric unit and the lactone moiety was confirmed by the HMBC correlation of the proton signal at $\delta 4.81(\mathrm{~d}, J 7.2 \mathrm{~Hz}, \mathrm{H}-9)$ with $\delta 33.5$ (C-10), 39.7 (C-3), and $174.8(\mathrm{C}-12)$. In addition, the correlations of $\delta 2.99(\mathrm{~m})$ with $\delta 82.6$ (C-9) and 84.4 (C-2) reinforced this proposal (Figure 2a). The relative configuration of the chromanone monomers was readily established to be the same as that of versixanthone $\mathrm{A}^{18}$ and previously described synthetic analogues. ${ }^{26}$ The cis relationship between $\mathrm{H}-9$ and $\mathrm{H}-10$ in the $\gamma$-butyrolactone moiety was supported by its typical coupling constant $\left({ }^{3} J_{\mathrm{H}-5, \mathrm{H}-6}=7.1 \mathrm{~Hz}\right) .{ }^{18,26}$ Additionally, nuclear Overhauser effect spectroscopy (NOESY) experiments confirmed the $\alpha$-orientations of H-9 and H-10 (Figure 2b).

In a previous investigation, Cai et al. ${ }^{26}$ reported some xanthone dimers from the solid fermentation of a soil
Alternaria strain, including chromanone homodimers with 6-6' linkage. However, authors reported that these derivatives were prone to degradation, thus, the stereochemistry investigations were discontinued. Moreover, these reported compounds named blennolides $\mathrm{H}$ and I displayed different coupling constant between $\mathrm{H}-9$ and $\mathrm{H}-10\left({ }^{3} J_{\mathrm{H}-5, \mathrm{H}-6}=4.0 \mathrm{~Hz}\right)$ indicating different diastereomer analogues. ${ }^{25} \mathrm{It}$ is important to notice that the trivial names blennolides $\mathrm{H}$ and I were also used in other works, ${ }^{16,25}$ but representing different structures (Figure 2c). Thus, compound $\mathbf{1}$ was assigned as a new chromanone homodimer, and to avoid any misunderstanding was named as being paecilin $\mathrm{D}$, in respect to the previously isolated dimeric xanthones bearing two chromanone monomers. ${ }^{19,27}$

Compound 7, obtained as a white amorphous solid from the strain VrTrb2 1.1 also displayed minor impurities, that could interfere in the optical activity. Its HRESIMS spectrum displayed a protonated molecule ion at $\mathrm{m} / \mathrm{z} 405.1530$ $\left([\mathrm{M}+\mathrm{H}]^{+}\right)$indicating a molecular formula of $\mathrm{C}_{21} \mathrm{H}_{24} \mathrm{O}_{8}$ (calculated 405.1544). The ${ }^{13} \mathrm{C}$ NMR and distortionless enhancement by polarization transfer (DEPT) 135 experiments evidenced the presence of twenty-one carbon atoms: three methyls, six methylenes, three methines, and nine quaternary ones. Olefine $(\delta 115.9,136.9,138.4,143.7$, 144.2 and 150.2) and carbonyl $(\delta 164.4,165.2,165.6,166.2$ and 172.2) like carbons evidenced the presence of alkenes, anhydrides, and an ester functional groups by means of their typical chemical shifts. The ${ }^{1} \mathrm{H}$ spectrum of 7 displayed two double triplet signals at $\delta 7.30$ (dt, $J 6.6$ and $15.8 \mathrm{~Hz}, \mathrm{H}-12$ ) and $\delta 6.21$ (dt, $J 1.6$ and $15.8 \mathrm{~Hz}, \mathrm{H}-11$ ). The coupling constants observed for these two signals indicated a double bond in trans orientation. ${ }^{28}$ The presence of a heptet-like signal at $\delta 2.21$ (hept, $J 6.8 \mathrm{~Hz}, \mathrm{H}-7$ ) was an indicative of a methinic hydrogen in a 3 -ethylpentane system. Four double (a)

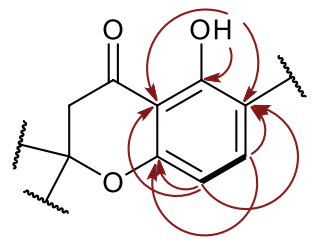

(b)

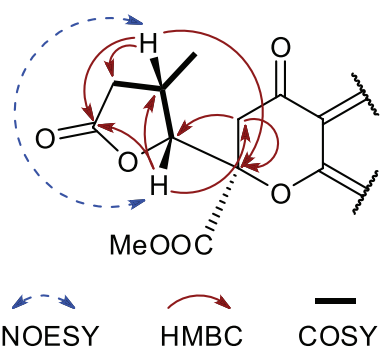

(c)<smiles>COC(=O)C1(C(=O)OC)CC(=O)c2c(ccc(-c3ccc4c(c3O)C(=O)CC(C(C)=O)(C3OC(=O)CC3C)O4)c2O)O1</smiles>

reported as blennolide $\mathrm{H}$ :

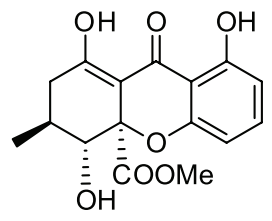

Figure 2. (a) COSY and HMBC correlations of the xanthone moiety for compound 1; (b) COSY, HMBC and NOESY correlations of the $\gamma$-lactone moiety for compound $\mathbf{1}$; (c) chemical structures of different compounds previously reported as blennolide $\mathrm{H}$. 
Table 1. ${ }^{1} \mathrm{H}(500 \mathrm{MHz})$ and ${ }^{13} \mathrm{C}(125 \mathrm{MHz})$ NMR data for compound $\mathbf{1}$, in chloroform- $d$ ( $\delta$ in ppm, $J$ in $\mathrm{Hz}$ )

\begin{tabular}{|c|c|c|}
\hline Position & $\delta_{\mathrm{H}}(J$ in $\mathrm{Hz})$ & $\delta_{\mathrm{C}}$ \\
\hline \multicolumn{3}{|l|}{1} \\
\hline 2 & & $84.4(\mathrm{C})$ \\
\hline 3 & $3.24, \mathrm{~m}$ & $39.7\left(\mathrm{CH}_{2}\right)$ \\
\hline 4 & & $194.1(\mathrm{C})$ \\
\hline $4 \mathrm{a}$ & & $107.5(\mathrm{C})$ \\
\hline 5 & & $159.2(\mathrm{C})$ \\
\hline 6 & & $117.6(\mathrm{C})$ \\
\hline 7 & $7.54, \mathrm{~d}(8.5)$ & $141.2(\mathrm{CH})$ \\
\hline 8 & $6.64, \mathrm{~d}(8.5)$ & $107.4(\mathrm{CH})$ \\
\hline $8 \mathrm{a}$ & & $158.4(\mathrm{C})$ \\
\hline 9 & $4.81, \mathrm{~d}(7.0)$ & $82.6(\mathrm{CH})$ \\
\hline 10 & $2.99, \mathrm{~m}$ & $33.5(\mathrm{CH})$ \\
\hline 11 & $\begin{array}{c}2.49, \mathrm{dd}(17.1,7.95) \\
2.71, \mathrm{dd}(17.0,8.2)\end{array}$ & $36.6(\mathrm{CH})$ \\
\hline 12 & & $174.8(\mathrm{CH})$ \\
\hline 13 & $1.34, \mathrm{~d}(7.0)$ & $14.8\left(\mathrm{CH}_{3}\right)$ \\
\hline 14 & & $169.0(\mathrm{C})$ \\
\hline 15 & $3.78, \mathrm{~s}$ & $53.7\left(\mathrm{CH}_{3}\right)$ \\
\hline $\mathrm{OH}-5$ & $11.92, \mathrm{~s}$ & \\
\hline \multicolumn{3}{|l|}{1 ' } \\
\hline $2^{\prime}$ & & $84.4(\mathrm{C})$ \\
\hline 3 ' & $3.24, \mathrm{~m}$ & $39.7\left(\mathrm{CH}_{2}\right)$ \\
\hline $4^{\prime}$ & & $194.1(\mathrm{C})$ \\
\hline $4 a^{\prime}$ & & $107.5(\mathrm{C})$ \\
\hline 5 & & $159.2(\mathrm{C})$ \\
\hline $6{ }^{\prime}$ & & $117.6(\mathrm{C})$ \\
\hline 7 & $7.54, \mathrm{~d}(8.5)$ & $141.2(\mathrm{CH})$ \\
\hline 8 & $6.64, \mathrm{~d}(8.5)$ & $107.4(\mathrm{CH})$ \\
\hline $8 a^{\prime}$ & & $158.4(\mathrm{C})$ \\
\hline $9^{\prime}$ & $4.81, \mathrm{~d}(7.0)$ & $82.6(\mathrm{CH})$ \\
\hline $10^{\prime}$ & $2.99, \mathrm{~m}$ & $33.5(\mathrm{CH})$ \\
\hline $11^{\prime}$ & $\begin{array}{l}2.49, \mathrm{dd}(17.1,7.95) \\
2.71, \mathrm{dd}(17.0,8.2)\end{array}$ & $36.6(\mathrm{CH})$ \\
\hline $12^{\prime}$ & & $174.8(\mathrm{CH})$ \\
\hline $13{ }^{\prime}$ & $1.34, \mathrm{~d}(7.0)$ & $14.8\left(\mathrm{CH}_{3}\right)$ \\
\hline $14^{\prime}$ & & $169.0(\mathrm{C})$ \\
\hline $15^{\prime}$ & $3.78, \mathrm{~s}$ & $53.7\left(\mathrm{CH}_{3}\right)$ \\
\hline $\mathrm{OH}-5$ & $11.92, \mathrm{~s}$ & \\
\hline
\end{tabular}

doublets at $\delta 2.45$ (dd, $J 6.8,13.9 \mathrm{~Hz}, \mathrm{H}-6 \alpha$ ), 2.59 (dd, $J 6.8$, $13.9 \mathrm{~Hz}, \mathrm{H}-6 \beta$ ), 2.37 (dd, $J$ 6.8, $13.9 \mathrm{~Hz}, \mathrm{H}-8 \alpha$ ), and 2.56 (dd, $J$ 6.8, $13.9 \mathrm{~Hz}, \mathrm{H}-8 \beta$ ) constituted two ABC-like spin systems. Beyond this, the presence of a typical methoxyl resonance $(\delta 3.67, \mathrm{~s})$ and two methyl groups $(\delta 0.99$ and 1.12) was observed (Table 2).

Heteronuclear single quantum coherence (HSQC) correlations between $\delta 3.67\left(1-\mathrm{OCH}_{3}\right)$ and the carbon at $\delta 52.0\left(1-\mathrm{OCH}_{3}\right)$, in addition to the HMBC correlation with $\delta 172.2$ (C-1) reinforced the proposal of an ester moiety. Additionally, correlations of the hydrogens $\delta 2.71(\mathrm{~m}, \mathrm{H}-2)$ and $2.77(\mathrm{~m}, \mathrm{H}-3)$ with $\mathrm{C}-1$ indicated the presence of a methyl propionate group (Figure 3). This group showed to be directly linked to a furan-2,5-dione group (maleic anhydride). This information was deduced by HMBC correlations of $\mathrm{H}-3$ with carbons at $\delta 143.7$ (C-4), 144.2 (C-5), and $165.2(\mathrm{C}-15)$, and from $\mathrm{H}-6 \alpha / \beta$ with $\mathrm{C}-5$ and $\delta 165.6$ (C-16). H- $6 \alpha / \beta$ signals also showed HMBC correlations with $\delta 28.2(\mathrm{C}-8)$ and 38.1 (C-7). COSY correlations between $\mathrm{H}-6 \alpha / \beta$ and with $\mathrm{H}-7$ (Figure 3 ), in addition to other HMBC and COSY (correlated spectroscopy) correlations for the $\mathrm{H}-8 \alpha / \beta$ and for $\mathrm{H}-19$ $(\delta$ 1.35) (Figure 3) confirmed the 3-ethylpentane system moiety linked to two furan-2,5-dione groups. A but-1-ene group linked to the second ring system was deduced by the HMBC correlations of H-11 with $\delta 138.4(\mathrm{C}-10)$ and 164.4 (C-18), by COSY correlations between H-14 $(\delta 1.12)$ with $\mathrm{H}-13$, and from H-12 with H-11. Therefore, compound 7 was found to be a new maleic anhydride substance named cordyanhydride A methyl ester: [methyl-3-(4-(2-((4-(but1-en-1-yl)-2,5-dioxotetrahydrofuran-3-yl)methyl)butyl)2,5-dioxotetrahydrofuran-3-yl)propanoate].

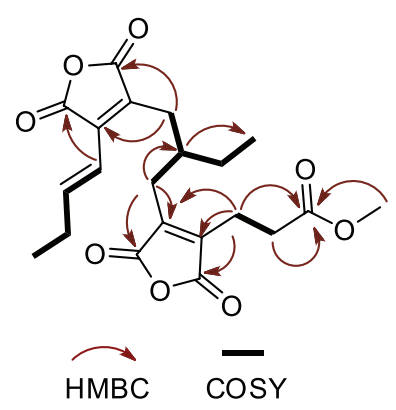

Figure 3. COSY and HMBC correlations of compound 7.

To assess if 7 was an artifact, DI-APCI-MS fingerprinting was employed. The corresponding mass spectrum of the main metabolites produced by Talaromyces sp. VrTrb2 1.1 (in the Supplementary Information (SI) section) displayed the protonated molecule ions of the acidic version (cordyanhydride $\mathrm{A}, \mathrm{m} / \mathrm{z}, 391$ ) and its corresponding methyl ester $(\mathrm{m} / \mathrm{z} 405)$, isolated for the first time in this communication. It is worth noticing that prior to the MS analysis methanol and silica gel were not used, reinforcing that compound $\mathbf{7}$ is not an artifact. Therefore, we concluded that $\mathbf{7}$ is a new naturally occurring compound.

Paecilins (1) are rare 2,2-disubstituted chroman-4-one compounds comprising monomers and biaryl single bonded dimers. Only three structures were previously described: paecilin A (homodimer) and paecilin B (monomer) isolated from Paecylomyces sp. (endophytic) ${ }^{19}$ paecilin B in Setophoma terrestris (soil), ${ }^{16}$ and paecilin C (heterodimer) in Penicillium sp. (marine organism). ${ }^{27}$ This is the first report of all identified polyketides in endophytic Talaromyces strains. 
Table 2. ${ }^{1} \mathrm{H}(400 \mathrm{MHz})$ and ${ }^{13} \mathrm{C}(100 \mathrm{MHz})$ NMR data for compound 7 , in chloroform- $d(\delta$ in ppm, $J$ in $\mathrm{Hz}$ )

\begin{tabular}{|c|c|c|}
\hline Position & $\delta_{\mathrm{H}}(J$ in $\mathrm{Hz})$ & $\delta_{\mathrm{C}}$ \\
\hline 1 & & $172.2(\mathrm{C})$ \\
\hline 2 & $2.68-2.73, \mathrm{~m}$ & $30.7\left(\mathrm{CH}_{2}\right)$ \\
\hline 3 & $2.76-2.79, \mathrm{~m}$ & $20.0\left(\mathrm{CH}_{2}\right)$ \\
\hline 4 & & $143.7(\mathrm{C})$ \\
\hline 5 & & $144.2(\mathrm{C})$ \\
\hline 6 & $\begin{array}{l}2.45, \mathrm{dd}(J 13.9,6.8), \mathrm{H} \alpha \\
2.59, \mathrm{dd}(J 13.9,6.8), \mathrm{H} \beta\end{array}$ & $28.7\left(\mathrm{CH}_{2}\right)$ \\
\hline 7 & 2.21, hept (J 6.8) & $38.1(\mathrm{CH})$ \\
\hline 8 & $\begin{array}{l}2.37, \mathrm{dd}(J 13.9,6.8), \mathrm{H} \alpha \\
2.56, \mathrm{dd}(J 13.9,6.8), \mathrm{H} \beta\end{array}$ & $28.2\left(\mathrm{CH}_{2}\right)$ \\
\hline 9 & & $136.9(\mathrm{C})$ \\
\hline 10 & & $138.4(\mathrm{C})$ \\
\hline 11 & $6.21, \mathrm{dt}(J 15.8,1.6)$ & $115.9(\mathrm{CH})$ \\
\hline 12 & $7.30, \mathrm{dt}(J 15.8,6.6)$ & $150.2(\mathrm{CH})$ \\
\hline 13 & $2.33-2.35, \mathrm{~m}$ & $27.5\left(\mathrm{CH}_{2}\right)$ \\
\hline 14 & $1.12, \mathrm{t}(J 7.4)$ & $12.5\left(\mathrm{CH}_{3}\right)$ \\
\hline 15 & & $165.2(\mathrm{C})$ \\
\hline 16 & & $165.6(\mathrm{C})$ \\
\hline 17 & & $166.2(\mathrm{C})$ \\
\hline 18 & & $164.4(\mathrm{C})$ \\
\hline 19 & $1.35, \mathrm{q}$ & $26.8\left(\mathrm{CH}_{2}\right)$ \\
\hline 20 & $0.99, \mathrm{t}(J 7.4)$ & $10.5\left(\mathrm{CH}_{3}\right)$ \\
\hline $\mathrm{OCH}_{3}-1$ & $3.67, \mathrm{~s}$ & $52.0\left(\mathrm{CH}_{3}\right)$ \\
\hline
\end{tabular}

Cordyanhydrides ( $\mathbf{7}$ and $\mathbf{8}$ ) were originally described from the insect pathogen fungus Cordyceps pseudomilitaris, ${ }^{24}$ and more recently from Paecilomyces tenuipes, ${ }^{29}$ and Dwayaangam colodena. ${ }^{30}$ So far, compounds bearing maleic anhydride moieties such as telfairic and itaconitin anhydrides, in addition to regular cordyanhydrides are known as insecticidal compounds. ${ }^{24}$ To the best of our knowledge a natural methyl ester from any of these compounds was not previously described.

\section{Antimicrobial assays}

Compounds 1-9 were tested for their antimicrobial activity against a panel of human and plant pathogens (Table 3). All fractionated extracts displayed at least a moderate antimicrobial activity to be selected and further investigated. $T$. stipitatus $\mathrm{DgCr} 22.1 \mathrm{~b}$ showed to be a prolific source of polyketides, especially xanthone dimers. Bioactivity-guided fractionation of this sample displayed that sub-fraction sP-6 had antifungal potential against

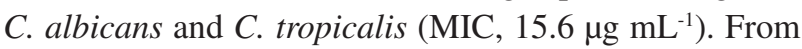
this sample, five different polyketides were assayed for their antimicrobial activities, in which, only paecilin D (1) and versixanthone (4) were active against the yeasts (MIC, 15.6 and $31.3 \mu \mathrm{g} \mathrm{mL} \mathrm{mL}^{-1}$, respectively). The compound

Table 3. Antimicrobial activity from the crude extracts obtained from the studied endophytic fungi

\begin{tabular}{|c|c|c|c|c|c|c|c|}
\hline \multicolumn{8}{|c|}{ Antimicrobial activity } \\
\hline Sample & B. cereus $^{\mathrm{b}}$ & E. coli ${ }^{\mathrm{b}}$ & S. aureus $^{\mathrm{b}}$ & R. solanacerum ${ }^{\mathrm{c}}$ & P. avellaneum ${ }^{\mathrm{c}}$ & C. albicans $^{\mathrm{b}, \mathrm{d}}$ & C. tropicalis $^{\mathrm{b}, \mathrm{d}}$ \\
\hline \multicolumn{8}{|c|}{ Talaromyces stipitatus. $\mathrm{DgCr} 22.1 \mathrm{~b}$} \\
\hline Broth:EtOAc ${ }^{\mathrm{a}}$ & n.a..$^{e}$ & $25 \mathrm{~mm}$ & n.a. & n.t. ${ }^{\mathrm{f}}$ & n.t. & $500^{g}$ & $500^{\mathrm{g}}$ \\
\hline Fraction sP-6 & - & $250^{\mathrm{g}}$ & n.a. & n.t. & n.t. & $15.6^{\mathrm{g}}$ & $15.6^{\mathrm{g}}$ \\
\hline Compound 1 & n.a. & n.a. & $>250^{\mathrm{g}}$ & n.t. & n.t. & $31.3^{\mathrm{g}}$ & $15.6^{\mathrm{g}}$ \\
\hline Compound 2 & n.t. & n.t. & n.t. & n.t. & n.t. & $125^{\mathrm{g}}$ & $125^{\mathrm{g}}$ \\
\hline Compound $\mathbf{3}$ & n.t. & n.t. & n.t. & n.t. & n.t. & $>250^{\mathrm{g}}$ & $>250^{\mathrm{g}}$ \\
\hline Compound 4 & n.t. & n.t. & n.t. & n.t. & n.t. & $31.3^{\mathrm{g}}$ & $31.3^{\mathrm{g}}$ \\
\hline Compound 5 & n.a. & n.a. & n.a. & n.t. & n.t. & $>250^{g}$ & $>250^{\mathrm{g}}$ \\
\hline \multicolumn{8}{|c|}{ Talaromyces sp. AnspCr1 1.1} \\
\hline Broth:EtOAc ${ }^{\mathrm{a}}$ & $15 \mathrm{~mm}$ & n.a. & $15 \mathrm{~mm}$ & n.t. & $10 \mathrm{~mm}$ & n.t. & n.t. \\
\hline Compound 6 & n.t. & n.t. & $>500^{\mathrm{g}}$ & n.t. & n.t. & $62.6^{\mathrm{g}}$ & $62.6^{\mathrm{g}}$ \\
\hline \multicolumn{8}{|c|}{ Talaromyces sp. VrTrb2 1.1} \\
\hline Broth:EtOAc ${ }^{\mathrm{a}}$ & n.a. & n.a. & n.a. & $10 \mathrm{~mm}$ & $20 \mathrm{~mm}$ & $250^{\mathrm{g}}$ & $500^{\mathrm{g}}$ \\
\hline Compound 7 & n.t. & n.t. & n.t. & n.a. & n.a. & n.a. & n.a. \\
\hline Compound $\mathbf{8}$ & n.t. & n.t. & n.t. & n.a. & n.a. & n.a. & n.a. \\
\hline Micelium:EtOAc/MeOH ${ }^{\mathrm{a}}$ & n.a. & n.a. & n.a. & $20 \mathrm{~mm}$ & $30 \mathrm{~mm}$ & n.t. & n.t. \\
\hline Compound 9 & n.t. & n.t. & n.t. & n.t. & n.t. & $>250^{\mathrm{g}}$ & $>250^{\mathrm{g}}$ \\
\hline Tetracycline $^{\text {h }}$ & $30 \mathrm{~mm}$ & & & & & & \\
\hline Fluconazole $^{\mathrm{i}}$ & & & & & $30 \mathrm{~mm}$ & $5^{\mathrm{g}}$ & $5^{\mathrm{g}}$ \\
\hline Ampicillin ${ }^{\mathrm{j}}$ & & $30 \mathrm{~mm}$ & $30 \mathrm{~mm}$ & $20 \mathrm{~mm}$ & & & \\
\hline
\end{tabular}


blennolide $\mathrm{G}(\mathbf{3})$ displayed a weak antifungal activity against the same fungi (MIC, $125 \mu \mathrm{g} \mathrm{mL}^{-1}$ ). Paecilin B, the monomeric unit of compound $\mathbf{1}$ isolated from both Talaromyces sp. AnspCr1 1.1 and $\mathrm{DgCr} 22.1 \mathrm{~b}$, showed a moderate antifungal activity (MIC, $62.6 \mu \mathrm{g} \mathrm{mL}^{-1}$ ), which indicates that dimerization enhances the activity. Other compounds, including the isolated cordyanhydrides were not active against the assayed pathogens (Table 3).

Secalonic acids and its related compounds, paecillins and blennolides, are poorly studied with respect to their pharmacological properties, although their structures and biosynthesis are well known. ${ }^{31}$ Anticancer activities were recorded for some derivatives against several tumor cell lines, where secalonic acid D is the most active. ${ }^{32}$ Concerning antimicrobial activities, blennolides ${ }^{21}$ and dicerandrols ${ }^{33}$ inhibited several pathogens. So far, only paecilin $\mathrm{C}$ was evaluated for its antibacterial potential, however, showed no activity. ${ }^{27}$ Therefore, this is the first report of the antifungal activity of a paecilin derivative.

\section{Conclusions}

The chemical investigation of the three Amazonian endophytic strains of Talaromyces afforded 13 different compounds. Among these, two undescribed compounds were fully characterized, the polyketide paecilin D (1) and the maleic anhydride cordyanhydride A methyl ester (7). The antimicrobial screening indicated that $\mathbf{1}$ and 4 (versixanthone) are promising antifungal agents. The obtained results highlight the immense potential of the Amazon rainforest to yield novel natural products as well as bioactive compounds.

\section{Supplementary Information}

Supplementary information is available free of charge at http://jbcs.sbq.org.br.

\section{Acknowledgments}

The authors are grateful to Conselho Nacional de Desenvolvimento Científico e Tecnológico (CNPq), Coordenação de Aperfeiçoamento de Pessoal de Nível Superior (CAPES), Fundação de Amparo à Pesquisa do Estado do Amazonas (FAPEAM), and Financiadora de Estudos e Projetos (FINEP) for their financial support. We also acknowledge the NMR laboratory of the Analytical Center from UFAM for their support with NMR spectra acquisition.

\section{References}

1. Tuomisto, H.; Ruokolainen, K.; Kalliola, R.; Linna, A.; Danjov, W.; Rodriguez, Z.; Science 1995, 269, 63.

2. Torsvik, V.; Øvreås, L.; Curr. Opin. Microbiol. 2002, 5 , 240.

3. Oliveira, L. G.; Pupo, M. T.; Vieira, P. C.; Quim. Nova 2013, 36, 1577.

4. Aly, A. H.; Debbab, A.; Proksch, P.; Appl. Microbiol. Biotechnol. 2011, 90, 1829.

5. Chu, Y. S.; Niu, X. M.; Wang, Y. L.; Guo, J. P.; Pan, W. Z.; Huang, X. W.; Zhang, K. Q.; Org. Lett. 2010, 12, 4356.

6. Li, H.; Huang, H.; Shao, C.; Huang, H.; Jiang, J.; Zhu, X.; Liu, Y.; Liu, L.; Lu, Y.; Li, M.; Lin, Y.; She, Z.; J. Nat. Prod. 2011, $74,1230$.

7. Guo, J.; Ran, H.; Zeng, J.; Liu, D.; Xin, Z.; Appl. Microbiol. Biotechnol. 2016, 100, 5323.

8. Guo, J. P.; Zhu, X. Y.; Zhang, C. P.; Chu, Y. S.; Wang, Y. L.; Zhang, J. X.; Wu, D. K.; Zhang, K. Q.; Niu, X. M.; J. Am. Chem. Soc. 2012, 134, 20306.

9. MacMillan, J.; Vanstone, A. E.; Yeboah, S. K.; J. Chem. Soc., Perkin Trans. 1972, 1, 2898.

10. Pons-Tostivint, E.; Thibault, B.; Guillermet-Guibert, J.; Trends Cancer 2017, 3, 454.

11. Koolen, H. H. F.; Soares, E. R.; Silva, F. M. A.; Almeida, R. A.; Souza, A. D. L.; de Medeiros, L. S.; Rodrigues-Filho, E.; de Souza, A. Q. L.; Quim. Nova 2012, 35, 771.

12. Koolen, H. H. F.; Menezes, L. S.; Souza, M. P.; Silva, F. M. A.; Almeida, F. G. O.; de Souza, A. Q. L.; Nepel, A.; Barison, A.; da Silva, F. H.; Evangelista, D. E.; de Souza, A. D. L.; J. Braz. Chem. Soc. 2013, 24, 880.

13. Koolen, H. H. F.; Soares, E. R.; da Silva, F. M. A.; de Souza, A. Q. L.; de Medeiros, L. S.; Rodrigues-Filho, E.; de Almeida, R. A.; Ribeiro, I. A.; Pessoa, C. O.; de Morais, M. O.; da Costa, P. M.; de Souza, A. D. L.; Nat. Prod. Res. 2012, 26, 2013.

14. Souza, A. D. L.; Rodrigues-Filho, E.; Souza, A. Q. L.; Pereira, J. O.; Calgarotto, K.; Maso, V.; Marangoni, S.; Silva, S. L.; Toxicon 2008, 51, 240.

15. de Souza, A. Q. L.; de Souza, A. D. L.; Astolfi-Filho, S.; Belém-Pinheiro, M. L.; Sarquis, M. I. M.; Pereira, J. O.; Acta Amazonica 2004, 34, 185.

16. da Silva, F. M. A.; de Lima, B. R.; Soares, E. R.; de Almeida, R. A.; Silva-Filho, F. A.; Corrêa, W. R.; Salvador, M. J.; de Souza, A. Q. L.; Koolen, H. H. F.; de Souza, A. D. L.; Pinheiro, M. L. B.; Rev. Bras. Farmacogn. 2015, 25, 11.

17. El-Elimat, T.; Figueroa, M.; Raja, H. A.; Graf, T. N.; Swanson, S. M.; Falkinham III, J. O.; Wani, M. C.; Pearce, C. J.; Oberlies, N. H.; Eur. J. Org. Chem. 2015, 109.

18. Zhang, W.; Krohn, K.; Ullah, Z.; Flçrke, U.; Pescitelli, G.; di Bari, L.; Antus, S.; Kurtán, T.; Rheinheimer, J.; Draeger, S.; Schulz, B.; Chem. Eur. J. 2008, 14, 4913. 
19. Wu, G.; Yu, G.; Kurtán, T.; Mándi, A.; Peng, J.; Mo, X.; Liu, M.; Li, H.; Sun, X.; Li, J.; Zhu, T.; Gu, Q.; Li, D.; J. Nat. Prod. 2015, 78, 2691.

20. Guo, Z.; She, Z.; Shao, C.; Wen, L.; Liu, F.; Zheng, Z.; Li, Y.; Magn. Reson. Chem. 2007, 45, 777.

21. Shirane, N.; Takenaka, H.; Ueda, K.; Hashimoto, Y.; Katoh, K.; Ishii, H.; Phytochemistry 1996, 41, 1308.

22. Zang, L.-Y.; Wei, W.; Wang, T.; Guo, Y.; Tan, R.-X.; Ge, H.-M. Nat. Prod. Bioprospect. 2012, 2, 117.

23. Lee, W. Y.; Park, Y.; Ahn, J. K.; Park, S. Y.; Lee, H. J.; Bull. Korean Chem. Soc. 2005, 26, 1464.

24. Ayer, W. A.; Attah-Poku, S. K.; Browne, L. M.; Orszanska, H.; Can. J. Chem. 1987, 65, 765.

25. Isaka, M.; Tanticharoen, M.; Thebtaranonth, Y.; Tetrahedron Lett. 2000, 41, 1657.

26. Cai, S.; King, J. B.; Du, L.; Powell, D. R.; Cichewicz, R. H.; J. Nat. Prod. 2014, 77, 2280.

27. Qin, T.; Johnson, R. P.; Porco Jr., J. A.; J. Am. Chem. Soc. 2011 , 133,1714 .
28. Bao, J.; Sun, Y. L.; Zhang, X. Y.; Han, Z.; Gao, H. C.; He, F.; Qian, P. Y.; Qi, S. H.; J. Antibiot. 2013, 66, 219.

29. Jaturapat, A.; Isaka, M.; Hywel-Jones, N. L.; Lertwerawat, Y.; Kamchonwongpaisan, S.; Kirtikara, K.; Tanticharoen, M.; Thebtaranonth, Y.; J. Antibiot. 2001, 54, 29.

30. Kikuchi, H.; Miyagawa, Y.; Sahashi, Y.; Inatomi, S.; Haganuma, A.; Nakahata, N.; Oshima, Y.; J. Org. Chem. 2004, 69, 352.

31. Sumarah, M. W.; Puniani, E.; Sørensen, D.; Blackwell, B. A.; Miller, D. J.; Phytochemistry 2010, 71, 760.

32. Wezeman, T.; Brase, S.; Masters, K. S.; Nat. Prod. Rep. 2015, 32,6 .

33. Wang, B. H.; Polya, G. M.; Planta Med. 1996, 62, 111.

34. Wagenaar, M. M.; Clardy, J.; J. Nat. Prod. 2001, 64, 1006.

Submitted: June 17, 2017

Published online: October 4, 2017 